\title{
Party Splits in Turkish Party System: The Case of Centre-Right Parties
}

\section{Özhan Demirkol}

To cite this article: Özhan Demirkol (2015) Party Splits in Turkish Party System: The Case of Centre-Right Parties, Turkish Studies, 16:1, 97-114, DOI: 10.1080/14683849.2015.1021247

To link to this article: http://dx.doi.org/10.1080/14683849.2015.1021247

$$
\text { 册 Published online: } 01 \text { Apr } 2015 .
$$

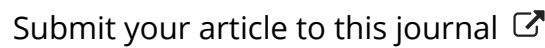

LIIl Article views: 302

Q View related articles $\sqsubset$

\section{View Crossmark data $₫$}




\title{
Party Splits in Turkish Party System: The Case of Centre-Right Parties
}

\author{
ÖZHAN DEMIRKOL
}

Department of Political Sciences, Bilkent University, Ankara, Turkey

\begin{abstract}
This study offers the first systematic analysis of party splits in Turkish electoral politics. It first explores party splits from major parties since the late 1940s before focusing on splits from three Turkish centre-right parties in the 1950s, 1960s, and 1990s. This article finds no detectable patterns between the entry costs measured by disproportionality, and the occurrence of party splits in Turkey. Instead, it argues that perceived demand for new parties and internal party dynamics, namely changes in party ideology and leadership consolidation, push the dissident factions out of the party and have a decisive influence over their decision to establish a new party. The article concludes with a note on the implications of this finding for contemporary Turkish party politics.
\end{abstract}

\section{Introduction}

In mid-December 2013, a corruption investigation ensnared several businessmen close to Recep Tayyip Erdoğan, the Turkish Prime Minister and the chair of the Justice and Development Party (AKP, Adalet ve Kalkınma Partisi). ${ }^{1}$ Erdoğan stated that the followers of an influential Muslim preacher, Fethullah Gülen, had been engaged in a conspiracy against him. ${ }^{2}$ When the government then introduced several laws to curb the power of the followers of Gülen in the bureaucracy and purged a number of police officers, nine AKP deputies resigned. There was speculation that these deputies intended to form a new party, but that has not happened yet. ${ }^{3}$

Such party switching and formation of new parties by dissident deputies is nothing new for Turkey. In fact, the AKP itself is 1 of 17 splinter parties that have had parliamentary representation since 1946 (Table 1). While there has been scholarly interest in the successful splinter parties, most of those parties that did not turn into significant competitors have not attracted much attention. Although they occur less in Western democracies, party splits are common in second and third wave democracies. ${ }^{4}$ However, comparative studies specifically focusing on party splits are few, although several studies provide in-depth analysis of individual cases of party splits. ${ }^{5}$ Studies on new party formation analyze the exogenous factors that influence

Correspondence Address: Özhan Demirkol, Department of Political Science, Bilkent University, 06800 Bilkent, Ankara, Turkey. Email: ozhan@bilkent.edu.tr 
Table 1. Splinter Parties with Parliamentary Representation in Turkey (1946-2011)

\begin{tabular}{|c|c|c|c|c|c|c|}
\hline Established party & $\begin{array}{c}\text { Turkish } \\
\text { acronym }\end{array}$ & Splinter party & $\begin{array}{r}\text { Turkish } \\
\text { acronym }\end{array}$ & $\begin{array}{c}\text { Date of } \\
\text { formation }\end{array}$ & $\begin{array}{l}\text { Votes received in } \\
\text { first elections }\end{array}$ & $\begin{array}{l}\text { Seats won in } \\
\text { first elections }\end{array}$ \\
\hline Republican People's Party & CHP & Democrat Party & DP & 1946 & - & 61 \\
\hline Democrat Party & DP & Nation Party (1) & MP (1) & 1948 & 4.6 & 1 \\
\hline Democrat Party & $\mathrm{DP}$ & Peasants' Party of Turkey & TKP & 1952 & 0.6 & 0 \\
\hline Democrat Party & $\mathrm{DP}$ & Freedom Party & HP & 1955 & 3.5 & 4 \\
\hline $\begin{array}{l}\text { Republican Peasants' and } \\
\text { Nation Party }\end{array}$ & CKMP & Nation Party (2) & MP (2) & 1962 & 6.3 & 31 \\
\hline Republican People's Party & CHP & Reliance Party & GP & 1967 & 6.6 & 15 \\
\hline Justice Party & $\mathrm{AP}$ & Democratic Party & $\mathrm{DkP}$ & 1970 & 11.9 & 45 \\
\hline Republican People's Party & CHP & Republican Party & $\mathrm{CP}$ & 1972 & Merged with the GP & 15 \\
\hline Social Democratic Populist Party & SHP & People's Labor Party & HEP & 1990 & $\begin{array}{l}\text { Electoral Coalition } \\
\text { with the SHP }\end{array}$ & 18 \\
\hline Social Democratic Populist Party & SHP & Socialist Unity Party & SBP & 1991 & $\begin{array}{l}\text { Did not participate } \\
\text { in elections }\end{array}$ & \\
\hline Motherland Party & ANAP & New Party & YP & 1993 & 0.1 & 0 \\
\hline Nationalist Action Party & MHP & Great Union Party & $\mathrm{BBP}$ & 1993 & $\begin{array}{c}\text { Electoral Coalition } \\
\text { with the ANAP }\end{array}$ & 8 \\
\hline True Path Party & DYP & Democrat Turkey Party & DTP & 1997 & 0.6 & 0 \\
\hline Democratic Left Party & DSP & Changing Turkey's Party & DEPAR & 1998 & 0.1 & 0 \\
\hline Virtue Party & FP & Justice and Development Party & AKP & 2001 & 34.3 & 363 \\
\hline Democratic Left Party & DSP & New Turkey Party & YTP & 2002 & 1.2 & 0 \\
\hline Justice and Development Party & $\mathrm{AKP}$ & Turkey Party & $\mathrm{TP}$ & 2009 & $\begin{array}{l}\text { Did not participate } \\
\text { in elections }\end{array}$ & \\
\hline
\end{tabular}

Notes: Numbers in parentheses distinguish parties with the same names. Only splinter parties with parliamentary representation are included. Compiled by the author from Kaynar et al., Cumhuriyet Dönemi Siyasi Partileri, 1923-2006; Türkiye Büyük Millet Meclisi, TBMM Albümü,19202010; Türkiye İstatistik Kurumu, Milletvekili Genel Seçimleri, 1923-2007. 
the calculations of the founders of both genuinely new and splinter parties, while works on party switching analyze the factors that influence the strategic calculations of deputies changing their party allegiance. ${ }^{6}$ Finally, studies on the institutional and social determinants of party system fragmentation deal with the indirect impacts of these factors on party splits. ${ }^{7}$ However, except for studies on the individual cases of party splits, others have neglected the intra-party dimension of politics.

This article therefore has two objectives. Firstly, it seeks to determine extent to which party splits in Turkey can be explained by the same factors that previous research on new party formation has revealed. Secondly, it attempts to explore the intra-party factors that play a role in party splits within the Turkish centre-right. The article starts by discussing the influence of electoral characteristics, namely disproportionality, turnout, and volatility, on party splits in Turkey. This is followed by an in-depth study, drawing on party bylaws and histories, biographies and newspaper articles, of three splits that have occurred in Turkey's centre-right, concerning the Democrat Party (DP, Demokrat Parti), the Justice Party (AP, Adalet Partisi), and the True Path Party (DYP, Doğru Yol Partisi). This study concludes that changes in party ideology and leadership consolidation pushed the dissenting factions out of the centre-right parties whereas the belief in the demand for a new party had a decisive influence over their decisions to establish a new party.

\section{Exogenous Factors in Party Splits}

Studies on new party formation and party system fragmentation have noted two main factors that dissidents of an established party take into account before leaving the parent organization: the presence of a neglected demand (i.e. the problem push) and the institutional facilitators of new party entrance (i.e. the opportunity pull). ${ }^{8}$ Although the studies that deal with party splits have proposed institutional factors like the degree of centralization or executive-legislative relations as explanatory variables, this work ignores them since they did not vary over time in Turkey. Besides, since the splinter parties with parliamentary representation were exempted from the costs to appear on the ballot, the analysis of these costs is excluded. Hence, this article focuses on the impacts of the electoral system on party splits in Turkey.

\section{Disproportionality}

Disproportionality is a measure of the aggregate gap between the proportion of votes obtained and the proportion of seats received by each party. ${ }^{9}$ Studies on new party formation and party system fragmentation agree that the electoral systems that convert votes to seats disproportionately result in fewer number of effective parties. ${ }^{10}$ The electoral systems that increase the number of votes needed to be won in order to gain seats in parliament tend to deter new comers. ${ }^{11}$ However, the Turkish case invalidates this expectation.

The second, the third, and the fourth column of Table 2, which shows the association between disproportionality and effective number of parliamentary parties, 
Table 2. Indicators of Entry Costs and Electoral Viability of New and Splinter Parties in Turkey (1950-2011)

\begin{tabular}{|c|c|c|c|c|c|c|}
\hline Year & $\begin{array}{c}\text { Number of } \\
\text { splinter parties }\end{array}$ & $\begin{array}{l}\text { Turkish acronyms } \\
\text { of splinter parties }\end{array}$ & Disproportionality & $\begin{array}{c}\text { Effective number of } \\
\text { parliamentary parties }\end{array}$ & Turnout rate & Volatility \\
\hline 1950 & 1 & MP (1) & 28.12 & 1.33 & 89.30 & - \\
\hline 1954 & 1 & TKP (1) & 32.23 & 1.15 & 86.60 & 4.5 \\
\hline 1957 & 1 & HP & 17.73 & 1.76 & 76.60 & 7.2 \\
\hline 1961 & 0 & - & 2.04 & 3.26 & 81.40 & 4.8 \\
\hline 1965 & 1 & MP (2) & 2.34 & 2.62 & 71.30 & 23.5 \\
\hline 1969 & 1 & GP & 8.98 & 2.35 & 64.30 & 11.25 \\
\hline 1973 & 1 & $\mathrm{DkP}$ & 6.84 & 3.32 & 66.80 & 14.4 \\
\hline 1977 & 0 & - & 6.59 & 2.47 & 72.40 & 18.0 \\
\hline 1983 & 0 & - & 6.84 & 2.53 & 92.30 & - \\
\hline 1987 & 0 & - & 22.30 & 2.05 & 93.30 & 38.5 \\
\hline 1991 & 1 & SBP & 11.34 & 3.58 & 83.30 & 16.6 \\
\hline 1995 & 2 & YP; BBP & 9.78 & 4.40 & 85.20 & 17.9 \\
\hline 1999 & 2 & DTP; DEPAR & 9.45 & 4.87 & 87.10 & 20.2 \\
\hline 2002 & 2 & AKP; YTP & 27.04 & 1.85 & 79.10 & 41.7 \\
\hline 2007 & 0 & - & 11.91 & 2.26 & 84.25 & 18.6 \\
\hline 2011 & 0 & - & 7.40 & 2.36 & 83.16 & 11.6 \\
\hline
\end{tabular}

Notes: Disproportionality is calculated according to the Gallagher Index and includes all parties and independents participating in the elections. Effective number of parliamentary parties weights parties by seats won. Volatility for pre-1980 period is calculated according to the Pedersen formula. Detailed formulas are provided in the Appendix. Volatility for the post-1980 period is derived from Tezcür, "Trends and Characteristics of the Turkish Party System". Only the splinter parties that competed in consecutive elections (including electoral coalitions) are included. 
demonstrates that disproportionality has not deterred dissident factions from forming their own parties in Turkey. For instance, despite the high level of disproportionality due to winner-take-all elections in the 1950s, dissident members of the DP founded their own parties. Similarly, although the ten percent national electoral threshold devised by the military after the 1980 intervention increased the votes needed to win parliamentary seats, party splits were frequent in the 1990s. Although the proportional electoral system of the 1960s decreased disproportionality, it did not encourage party splits after the 1973 elections. In this sense, except for the period between 1961 and 1973, disproportionality was far from constituting a barrier for the entrance of splinter parties.

\section{Electoral Viability of New Parties}

Dissident factions can be encouraged to split from their established parties by the perceived demand for a new party. That is, political entrepreneurs are likely to invest their resources in a new party when they believe that their party will attract sufficient support. ${ }^{12}$ This belief might stem from a transformation of the cleavage structure that leads to the rise of a new voter base with new concerns. ${ }^{13}$ If the established parties are reluctant to meet these new demands, the dissident faction may assume that a new splinter party could attract the support of this dissatisfied vote base. ${ }^{14}$ Alternatively, the poor economic performance of the incumbent parties may encourage voters to cast their vote for "untried" parties. Consequently, dissident party members may calculate that they can win the support of dissatisfied voters if they invest in a new party. $^{15}$

Intra-variation studies on new party formation suggest three ways to assess the probability of electoral support for a potential splinter party. Firstly, party dissidents may use pre-election polls to estimate support for their new party. If the polls show voter discontent with the established parties or support for a new party, then the dissidents may defect from their established party. In Turkey, for example, during the second half of the 1990s and the early 2000s, pre-election polls indicated that there was a significant number of undecided and protest votes and support for the potential new parties. ${ }^{16}$ While this may have helped trigger the departure of dissidents from their parties, there were no pre-election polls until the 1977 elections, so the political entrepreneurs of the pre-1980 period had to rely on other indicators of electoral viability. ${ }^{17}$

A second way to assess the potential support for a new party is turnout rates. Dissident factions may consider the decreasing turnout rates in previous elections as signaling voter discontent with the established parties and calculate that a new party can receive significant support, leading to an increase in splinter parties. ${ }^{18}$ Analysis of Turkish elections supports this expectation for the pre-1980 period. Turnout rates decreased to 38.30 percent in the 1955 municipal elections, which was boycotted by the opposition parties, just before the governing DP split. ${ }^{19}$ The second and fifth columns of Table 2 demonstrate the association between decreasing turnout rates and party splits in the $1960 \mathrm{~s}$, whereas splits decreased once turnout rates rise 
with the 1973 elections. However, after the introduction of the compulsory voting in 1983, the association between turnout rates and party splits disappears, making turnout rate no longer a valid indicator for estimating support for a potential splinter party for the post-1980 period.

The third indicator of the level of party system institutionalization is the level of electoral volatility. ${ }^{20} \mathrm{Un}$-institutionalized party systems, characterized by low popularity of established parties, weak grounding of parties in civil society and weak partisan identities, encourage party splits since the dissident factions may consider that their new parties can win the support of floating voter base. ${ }^{21}$ Consequently, party splits may increase if the electoral volatility is high.

As the second and the seventh columns of Table 2 demonstrate, party splits in Turkey were associated with the high levels of volatility in both the 1960s and the 1990s. However, the splits in the DP despite the lower volatility in the 1950s and the absence of party splits after the 1973 elections despite the increasing volatility need to be explained. Moreover, the association between volatility and party splits is problematic due to the reciprocal relationship between these two variables. That is, volatility may result from voters' support for the newly formed parties, or it may cause dissident political entrepreneurs to believe that they can win the votes of free-floating voters by investing in a new party. ${ }^{22}$ Therefore, given that the disproportionality did not constitute a barrier for party splits and that the indicators of the electoral viability used in the literature were not sufficient for explaining party splits in Turkey, a closer look at the internal dynamics of political parties may provide clues for explaining the phenomenon.

\section{Party Splits in the Turkish Centre-Right}

Until 2002, all three centre-right parties shared the so-called "1946 Spirit," which indicated opposition to single-party authoritarianism. The DP was the governing party from 1950 until the military intervention in 1960 . The AP became the main successor of the DP and ruled the country from 1965 to 1971. After all existing parties were banned following the military intervention of 1980, the DYP was founded to succeed the AP. The following section analyses three cases of party splits in the Turkish centre-right and discusses the importance of exogenous and intra-party factors for explaining them. However, before this, a brief history of intra-party conflicts in Turkey is required (Table 3).

The first split analyzed in this study occurred in the DP in 1955. The split was a result of the demands of 19 DP deputies for the removal of the authoritarian legacies of the single-party period, which had been promised by the DP. Specifically, the dissident DP deputies, who became known as the "advocators of the right to proof" (Ispatçllar) demanded that journalists who had been taken to court should have the right to defend what they had written. ${ }^{23}$ However, the DP's leader Adnan Menderes expelled the leaders of the dissenting faction before the party's fourth general congress in October 1955. ${ }^{24}$ The expelled dissidents had expected that between 100 and 168 DP deputies would join their new party. ${ }^{25}$ However, the remaining dissident 
Table 3. Factions in the Centre-Right Parties

\begin{tabular}{|c|c|c|c|}
\hline & DP & $\mathbf{A P}$ & DYP \\
\hline $\begin{array}{l}\text { Name(s) of } \\
\text { dissenting } \\
\text { faction }\end{array}$ & İspatçılar, Ondokuzlar & Bilgiççiler, Yetmişkiler & Yeni Oluşumcular \\
\hline $\begin{array}{l}\text { Leader(s) of } \\
\text { dissenting } \\
\text { faction }\end{array}$ & $\begin{array}{l}\text { Fevzi Lütfi } \\
\quad \text { Karaosmanoğlu }\end{array}$ & Saadettin Bilgiç & $\begin{array}{l}\text { Hüsamettin Cindoruk, } \\
\text { İsmet Sezgin, } \\
\text { Köksal Toptan }\end{array}$ \\
\hline $\begin{array}{l}\text { Stated } \\
\text { reasons of } \\
\text { dissent }\end{array}$ & $\begin{array}{l}\text { The DP chair abandoned } \\
\text { intra-party democracy } \\
\text { and broke his promise } \\
\text { to democratize the } \\
\text { regime }\end{array}$ & $\begin{array}{l}\text { The AP leader turned } \\
\text { the party from a party } \\
\text { of principles into a } \\
\text { party of personal } \\
\text { interests }\end{array}$ & $\begin{array}{l}\text { The DYP leader } \\
\text { turned the party } \\
\text { from a party of } \\
\text { principles into a } \\
\text { party of personal } \\
\text { interests }\end{array}$ \\
\hline $\begin{array}{l}\text { Demands of } \\
\text { the } \\
\text { dissenting } \\
\text { faction }\end{array}$ & $\begin{array}{l}\text { Democratization of the } \\
\text { regime }\end{array}$ & $\begin{array}{l}\text { Abandonment of the } \\
\text { expulsion of the } \\
\text { intra-party opposition }\end{array}$ & $\begin{array}{l}\text { Unification of the } \\
\text { Centre-Right } \\
\text { against the rising } \\
\text { political Islam }\end{array}$ \\
\hline $\begin{array}{l}\text { Years of } \\
\text { intra-party } \\
\text { conflict }\end{array}$ & 1955 & $1969-1970$ & $1995-1997$ \\
\hline $\begin{array}{l}\text { Outcome of } \\
\text { the conflict }\end{array}$ & Expulsion and resignation & $\begin{array}{l}\text { Expulsion and } \\
\text { resignation }\end{array}$ & $\begin{array}{l}\text { Expulsion and } \\
\text { resignation }\end{array}$ \\
\hline $\begin{array}{l}\text { Name of } \\
\text { splinter } \\
\text { party }\end{array}$ & $\mathrm{HP}$ & Democratic Party & DTP \\
\hline $\begin{array}{l}\text { Ideology of } \\
\text { splinter } \\
\text { party }\end{array}$ & Liberal & $\begin{array}{l}\text { Right of center } \\
\text { (conservative- } \\
\text { nationalist) }\end{array}$ & Center-right \\
\hline
\end{tabular}

Note: Names of dissenting factions are ascribed by the journalists.

deputies chose to struggle within the party, using a vote of confidence to bring down the DP government in November $1955 .{ }^{26}$ Afterwards, Menderes promised to democratize the regime. ${ }^{27}$ Despite Menderes's apparent retreat, the expelled deputies did not believe in his sincerity and formed the Freedom Party (HP, Hürriyet Partisi) in late $1955 .^{28}$

The second split occurred in the ruling AP in 1970. Since its foundation, the AP had been factionalized into three groups, namely the moderates (Mutediller), the conservative hardliners (Müfritler), and the radical nationalists, who were united around the common goal of "bringing justice to the imprisoned DP leaders" but disagreed over the strategies to be employed against the military. ${ }^{29}$ Following the death of party's first chair Ragıp Gümüşpala, Süleyman Demirel was selected as the new AP chair. Demirel initially opted to balance the conservatives known as the "adherents of Saadettin Bilgiç" (Bilgiççiler) and the moderates, called the "sworns" 
(Yeminliler). However, following the 1969 elections, Demirel abandoned his conciliatory stance by expelling some of the Bilgiççiler from the party ${ }^{30}$ With the support of the now-released DP leaders, who were disappointed with Demirel's reluctance to restore their political rights, the Bilgiççiler revolted, accused Demirel of abandoning intra-party democracy and turning the party into a machine for satisfying his personal interests. ${ }^{31}$ Some of the dissidents then cooperated with the main opposition party, to formally accuse Demirel of misconduct. ${ }^{32}$ Finally, the Bilgiççiler caused the second Demirel government to fall by voting against it. ${ }^{33}$ Nevertheless, Demirel did not retreat, instead expelling 26 deputies before the fifth general congress. Once Demirel won the fifth general congress, the expelled dissidents founded the Democratic Party (DkP, Demokratik Parti) as the "true successor" of the outlawed DP.

The AP's successor after the 1980 intervention was the DYP. After Demirel became President of the Turkish Republic in 1993, Tansu Çiller, a professor of economics, who had no relations with the DP's tradition, was selected as the new party chair. Çiller gradually consolidated her control over the extra-parliamentary party by removing some of Demirel's close associates and co-opting others. ${ }^{34}$ Çiller's attempt to form a minority government prior to the 1995 elections led to reaction by several deputies headed by Hüsamettin Cindoruk, the former Speaker of the Turkish Grand National Assembly and a potential challenger for Çiller's position. The minority government was unable to win vote of confidence, with 13 DYP deputies, who were later expelled from the party, voting against it or abstaining. ${ }^{35}$ Following the 1995 elections, the DYP's decision to form a coalition with the pro-Islamist Welfare Party (RP, Refah Partisi) provoked further discontent that ended with the resignation of Çiller's remaining opponents, known as the "supporters of new formation" (Yeni Oluşumcular). ${ }^{36}$ These dissidents initially expected that they would be accompanied by a significant number of deputies, not only from the DYP but also the Motherland Party (ANAP, Anavatan Partisi), the mainstream centre-right party that ruled the country between 1983 and $1991{ }^{37}$ However, once their expectations failed to come true, they formed the Democrat Turkey Party (DTP, Demokrat Türkiye Partisi) in January 1997.

As previously noted, dissidents from both the DP and the DYP left their parent organization even though the electoral systems had a disproportional vote to seat conversion. The level of disproportionality prior to the split in the DP was 32.23 per cent, while, although the disproportionality level prior to the split in the DYP was 9.78 percent, the ten percent national threshold had increased the votes needed to win parliamentary seats. Thus, both cases contradict the expectation that higher disproportionality should deter the deputies, who are mainly motivated by the re-election goal. However, while re-election goal is an important goal for politicians, they may also seek to realize certain other policy goals. Hence, as some studies have already found, such politicians may decide to invest their resources in a new party in order to articulate certain policies even under electoral systems producing disproportional conversion of votes to seats. ${ }^{38}$ One might then ask why the DP and the DYP dissidents opted to form a new party rather than compete for their policy goals within 
their parties. The answer to this question is closely related with the potential support for a new party.

The analysis in the first part of the article, which reveals the limitations with the three indicators used to assess the viability of new parties, should not lead to conclude that they are irrelevant. On the contrary, these indicators seem to have led the dissident factions in Turkish centre-right parties to conclude that their new parties could receive electoral support. For example, turnout rates that decreased from 86.60 percent in 1954 general elections to 38.30 percent in 1955 municipal elections and from 71.30 percent in 1965 general elections to 64.30 percent in 1969 general elections may have been interpreted by DP and AP dissidents respectively that a new party could attract sufficient electoral support. On the other hand, increasing levels of volatility in the 1990s seems to have led DYP dissidents to conclude that a new centre-right party uniting the fragmented centre-right could attract electoral support. In fact, the dissidents expected that such a party would receive around 25 percent of the votes. ${ }^{39}$ However, although perceived demand for a new party seems to lead the dissidents to establish new parties, what pushed them from the established parties remains a question to be answered. Since party splits lie on the borders of intra-party and inter-party relations, a detailed analysis of intra-party factors may reveal the reasons behind party splits on Turkish centre-right. ${ }^{40}$ There- $^{-}$ fore, the analysis of the source of disagreement and power distribution among competing factions is required.

\section{Perceived Party Change}

In all three cases of party splits described above, the members of the dissenting factions believed that their party had deviated from its founding principles under the leadership of the current chair. The Íspatçlar of the DP argued that the party had been originally formed to enhance freedom and democracy but that it had failed to democratize the regime under Menderes's leadership. ${ }^{41}$ They argued that the party was no longer the same as it was when in opposition so a new party was required to revitalize its founding "anti-authoritarian spirit."

The dissidents of the AP and the DYP also claimed to represent the so-called "1946 spirit." For the Bilgiççiler, the AP chair had betrayed the party's ideals to obtain personal gain. ${ }^{43}$ The "unlawful and undemocratic expulsion of the true democrats" following the 1969 elections and the support of the party chair for the Yeminliler were taken as evidence of the party chair's attempt to establish one-man rule over the party. ${ }^{44}$ Hence, they claimed, the party was changing from a party of ideals to a party of personal interests. ${ }^{45}$

The same line of argument was voiced by the Yeni Olusumcular of the DYP, who opposed Çiller's attempt to create a new, urban, modern, and youthful image for the party by excluding the party's "real owners, who had dedicated their lives to the realization of the 1946 spirit." 46 For the Yeni Oluşumcular, Çiller's attempts to replace the veterans of the Democrat tradition with her followers, and her decision to form a governing coalition with the Islamist RP, was evidence that she wished 
to turn the party from a party of mission into a personal machine. ${ }^{47}$ Corruption allegations against the party leaders in all cases further reinforced the perception of the dissidents about the party change. ${ }^{48}$ This perception led the dissident factions to conclude that a "purifier party" was required to revitalize the founding principles of the established parties. ${ }^{49}$

The perceived party change may have led the dissenting factions to feel unable to voice their dissent within the party. ${ }^{50}$ Nevertheless, perceived party change is not a sufficient condition for party splits on its own because the dissident faction may attempt to prevent unwanted party change if it has enough power. Hence, power distribution between the competing factions is also crucial for explaining the variation in the responses of the party leaders toward competing demands. Although the observers of Turkish politics relate party splits to the tendency of party chairs to expel their opponents, there are instances that the leaders refrained from exclusionary measures. ${ }^{51}$ For example, the AP's first chair opted for a compromise between the factions during the party's formative years. ${ }^{52}$ In a similar vein, Demirel accommodated the demands of the dissenting faction until the 1969 elections. ${ }^{53}$ Similarly, although DP leader Menderes expelled dissident deputies in October 1955, he promised to meet their demands only one month after their expulsions. ${ }^{54}$ Finally, DYP leader Çiller co-opted some of her opponents prior to the 1995 elections while ignoring their demands after the elections. ${ }^{55}$ The reason behind these strategies is closely related to the distribution of factional power within party organization.

\section{Weakness of the Dissenting Factions Within the Ruling Party Face}

Political parties have three faces: party on the ground, party in public office, and the party in central office. ${ }^{56}$ The party face, which is primarily responsible for the nomination of deputies and party officers, disciplining party members and determining party policies and strategies, has the upper hand in controlling the party organization. ${ }^{57}$ The weakness of a dissident faction within the ruling party face makes it easy for the party leader to ignore their demands, even in times of a serious intraparty conflict. Therefore, a closer look at the organizational characteristics of the established parties may explain party splits.

All three parties discussed here adopted a decentralized party model in which the extra-parliamentary party held the upper hand in deciding on party policies and strategies, disciplining dissident deputies, and nominating candidates. Accordingly, the general congresses were the highest decision-making organs, setting policies and strategies. ${ }^{58}$ The General Administrative Councils (GACs), whose members were selected at the general congresses, were responsible for implementing the congresses' decisions and for administering party organization. ${ }^{59}$ Although the parliamentary groups were granted some limited autonomy, deputies were nevertheless obliged to act in line with the parties' basic principles and programs and the binding decisions taken by the parliamentary groups. ${ }^{60}$ Moreover, the deputies were subject to disciplinary action if they violated the decisions of the central office or the principle of solidarity. ${ }^{61}$ Finally, deputies' seats were far from secure, as the extra-parliamentary 
parties in all cases were responsible for nominating candidates. The DP and the AP by-laws stipulated that the candidates would be chosen by primary elections, whereas the DYP by-law authorized the GAC to determine the nomination methods. ${ }^{62}$ However, the GACs of the AP and the DYP could veto those registering for nominations. ${ }^{63}$ Given that the GACs of all parties had the right to dismiss local executive boards, the faction that held the majority in the GAC had the power to influence, if not to determine, the nominations. ${ }^{64}$ Consequently, the outcome of the intra-party factional competition depended on the distribution of seats among the factions on the GACs.

The third row in Table 4 shows that the dissenting factions remained a minority in each party's central office before the party split. The Ispatçlar had two seats in the DP's GAC, which was composed of 15 seats; the Bilgiççiler held 8 out of 27 seats in the AP's GAC, while the dissidents of the DYP won 12 out of 40 seats of the GAC at the 1993 congress. Given their minority position, the dissidents were unable to change their party leadership from within the party. Additionally, they were a minority in each parliamentary party, with the total number of deputies switching to the splinter parties for the DP, AP, and DYP being 36, 37, and 23 out of 503, 256, and 135 seats, respectively. Since they remained in minority in both the GAC and the parliamentary parties, the dissidents could not use these platforms to reverse the process of party change.

\section{Sources of Party Leaders' Legitimacy: Party Leader Selection Methods and Electoral Performance}

Although in all three cases conflict over party change and the weakness of the dissenting factions laid the ground for their expulsion, one might wonder why the party leadership refused to accommodate the minority faction's demands, even if doing so led to a party split. The answer to this question may be related with the issue of the legitimacy of the party leadership. A century ago, Michels stated that party leaders considered themselves as representing the party's collective will, therefore, demanding

Table 4. Seats Held by the Dissident Members in the Parliamentary and Extra-parliamentary Parties

\begin{tabular}{lccc}
\hline & DP & AP & DYP \\
\hline $\begin{array}{l}\text { Year of last general congress prior to the intra-party conflict } \\
\text { Ratio of dissident members to the total number of seats in the Central }\end{array}$ & 1951 & 1968 & 1993 \\
$\quad$ Executive Board (in percent) & 29.63 & 30.00 \\
$\begin{array}{l}\text { Percentage of seats held by the party in the parliament } \\
\text { Ratio of dissident deputies to the total number of party deputies (in }\end{array}$ & 7.16 & 14.45 & 17.04 \\
percent) & & & \\
\hline
\end{tabular}

Notes: Dissident members are the executive board members, who switched to splinter parties. Dissident deputies are the deputies, who switched to splinter parties. 
obedience and submission to their personal will by pointing out the democratic nature of their election. ${ }^{65}$ Two factors reinforce this tendency: party leader selection methods and the previous electoral performances of the established parties.

In all three cases, the party leaders were elected at the general congresses that were composed of both ex officio members and delegates selected at provincial congresses. ${ }^{66}$ The third row of Table 5 demonstrates that party chairs received the support of nearly all delegates at their general congresses prior to the splits, while the fifth row shows that they confirmed their leadership after the splits. Hence, in response to the dissident members' criticisms about the lack of intra-party democracy, the party leaders pointed out to the will of the general congress ${ }^{67}$ For example, the AP's leader argued that the dissidents' claims about the lack of intra-party democracy were null and void since the party administration was democratically elected. ${ }^{68}$ Similarly, the DP's leader stated that the party organs were democratically selected, reminding the dissenting members that they had previously agreed to the measures that they were now criticizing. ${ }^{69}$

In addition to the congress results, previous electoral results increased the legitimacy of the party leadership. The DP increased its votes from 55.2 percent in 1950 to 58.4 percent in the 1954 elections. Although the AP's votes fell from 52.9 percent in 1965 to 46.6 percent in the 1969 elections, the party continued to hold a majority of the seats in the lower house. Both parties' leaders interpreted these electoral victories as confirmation of their leadership by the voters. For example, following the 1954 elections, the DP chair stated that he did not need to consult liberal journalists since the voters had supported his policies, while one of the Bilgiççiler criticized Demirel for interpreting the results of the 1969 elections as his personal success. ${ }^{70}$ Finally, although the DYP's votes decreased from 27 percent in 1991 to 19.2 percent in 1995, the party's electoral performance was far nevertheless better than the dissidents had expected, who had viewed the elections as a litmus test for Çiller's chair. ${ }^{71}$ The DYP leader's unanticipated victory gave legitimacy to her continued rule. Consequently, the party leaders, who considered themselves as representatives of the party's collective will demanded obedience to their rule.

Table 5. General Congress and Electoral Results

\begin{tabular}{lccc}
\hline & DP & AP & DYP \\
\hline Year of last general congress prior to the split & 1951 & 1968 & 1993 \\
$\begin{array}{l}\text { Votes for the party chair in the last general congress (in percent) } \\
\text { Year of the first congress after the resignations/expulsions }\end{array}$ & 94.95 & 100.00 & 86.01 \\
$\begin{array}{l}\text { Votes received by the party chair at the first congress } \\
\text { after the resignations/expulsions (in percent) }\end{array}$ & 97.66 & 94.68 & 90.65 \\
$\begin{array}{l}\text { Votes for the party in the last elections prior to } \\
\text { the split (in percent) }\end{array}$ & 58.40 & 46.60 & 19.20 \\
\begin{tabular}{l} 
Change in party's votes in the last two elections (in percent) \\
\hline
\end{tabular} & 3.20 & -6.30 & -7.80 \\
\hline
\end{tabular}




\section{Conclusion}

Scholarly works on party system fragmentation and new party formation have revealed the importance of exogenous factors, such as the electoral system and transformation of social cleavages for explaining party splits. The analysis of the Turkish case shows that disproportionality does not necessarily prevent party splits. This study's detailed analysis of three splits in Turkish centre-right parties reveals that changes in party ideology and leadership consolidation pushed the dissenting factions out of the centre-right parties whereas the belief in the demand for a new party that would revitalize the established parties' founding principles had a decisive influence over their decisions to establish a new party. Hence, the analysis shows that we should not underestimate the role of intra-party dynamics and factors in party splits. Rather, paying equal importance to both endogenous and exogenous factors and dynamics may substantially improve our understanding of party splits.

Although the findings are limited to three cases of party splits in Turkey, they imply that factional tendencies can survive under electoral systems that increase the votes required to win parliamentary seats. However, this outcome depends on the perceived viability of a new party, the source of factional conflicts that motivate the splinter party's political project, and the power distribution among the competing factions. In Turkey, since the 2002 elections, decreasing electoral volatility and increasing turnout rates, which indicate that the party system has stabilized, may have been impeding factions from forming splinter parties. Regarding the recent developments in the AKP, the weakness of the dissident members in the party organization and the legitimacy of the AKP leader, whose leadership has been reconfirmed by each election and general congress, seem to push the deputies that resigned out of the party. However, the AKP's victory in the municipal elections of March 30, 2014, despite corruption allegations may have indicated to them that a new party might be unable to attract sufficient voter support. This implies that dissident AKP deputies will be less likely to invest in a new party in the near future.

\section{Acknowledgments}

The author thanks Zeki Sarıil from Bilkent University and Cenk Saraçoğlu from Ankara University and the reviewers for their valuable suggestions.

\section{Disclosure statement}

No potential conflict of interest was reported by the author.

\section{Notes}

1. "Growing Corruption Inquiry Hits Close to Turkish Leader." New York Times, December 19, 2013.

2. "Whose Turkey Is It?" New York Times, February 5, 2014.

3. "Ertuğrul Günay İstifa Eden Vekillerle Yeni Parti Kuruyor.” Bugün, March 25, 2014.

4. See Cotta, "Structuring the New Party Systems"; Harmel and Robertson, "Formation and Success of New Parties"; and Hug, Altering Party Systems. 
5. See Charney, "Class Conflict and the National Party Split"; Cole, "Factionalism, the French Socialist Party and the Fifth Republic"; Katrak, "India's Communist Party Split"; and Nuvunga and Adalima, Mozambique Democratic Movement (MDM).

6. See Desposato, "Parties for Rent?"; Desposato and Scheiner, "Governmental Centralization and Party Affiliation"; and Heller and Mershon, "Switching in Parliamentary Parties".

7. See Bochsler, "The 'Normalization' of Party Systems" and Olson, "Party Formation and Party System Consolidation in the New Democracies of Central Europe". For studies on party system fragmentation in Turkey, see Sayarı, "The Turkish Party System in Transition"; Özbudun and Tachau, "Social Change and Electoral Behavior in Turkey"; and Çarkoğlu, "The Turkish System in Transition".

8. Hug, Altering Party Systems, 37.

9. Colomer, The Handbook of Electoral System Choice, 326.

10. See Mainwaring, "Politicians, Parties, and Electoral Systems"; Selb and Pituctin, "Methodological Issues in the Study of New Parties' Entry and Electoral Success"; and Willey, "Institutional Arrangements and the Success of New Parties in Old Democracies".

11. Tavits, "Party Systems in the Making," 115.

12. Hug, "Studying the Electoral Success," 192.

13. See Inglehart, "The Silent Revolution in Europe" and Ignazi, "The Silent Counter-Revolution".

14. Inglehart and Flanagan, "Value Change in Industrial Societies," 1297 and Hug, Altering Party Systems, 45.

15. Başlevent, Kirmanoğlu, and Şenatalar, "Empirical Investigation of Party Preferences," 558.

16. "Yeni Oluşumun Liderlik Arayışı." Milliyet, September 12, 1996; "Üç Ayrı Ankete Göre Siyasetin Tablosu." Hürriyet, January 2, 2001; and "Hürriyetim'in Anketi: Yüzde 21.7 Hala Kararsız." Hürriyet, August 6, 2002.

17. Kalaycioğlu and Çarkoğlu, Turkish Democracy Today, 167.

18. Lago and Martinez, "Why New Parties," 9.

19. "Seçimlerin Kati Neticesi." Milliyet, October 1, 1955.

20. Hazama, Electoral Volatility in Turkey, 1.

21. Enyedi, "Party Politics in Post-Communist Transition," 229.

22. Krouwel and Bosch, "Explaining the Emergence of New Parties," 7.

23. Zürcher, Turkey, 231.

24. “9 Mebus DP'den İhraç Edildi.” Milliyet, October 10, 1955.

25. Simav, Turan Güneş'in Siyasi Kavgalarl, 50.

26. Çakmak, "Türk Siyasal Yaşamında," 162.

27. Ibid., $162-3$.

28. Nutku, Demokrat Parti Neden Çöktü, 298.

29. Sakallığlu, AP-Ordu İlişkileri, 122.

30. Bilgiç, Hattralar, 200.

31. Demokratik Parti, 72'ler Hareketi, 16-22; Bilgiç, Hatıralar, 274; and Bozbeyli, Demokratik Săg, 164-5. Although the imprisoned DP members had been released, a constitutional amendment was required for their return to active politics. The fourth AP general congress voted for a constitutional amendment to restore the DP members' political rights. However, under pressure from the military and the President, the AP leader backed down so as not to provoke another military intervention. In response, the former President and the first chair of the DP, Celal Bayar, called on former DP voters to boycott the elections.

32. Gürkan, 50. Yll, 256-9.

33. Demokratik Parti, 72'ler Hareketi, 43-5.

34. Cizre, "From Ruler to Pariah," 95.

35. "Cindoruk'a İhraç." Milliyet, October 17, 1995.

36. "DYP'den Tarihi Kopuş." Milliyet, July 17, 1996.

37. "Tek Hedef Bütünleşme.” Milliyet, July 20, 1996.

38. Harmel and Robertson, "Formation and Success of New Parties," 507.

39. "Yeni Oluşumun Liderlik Arayışı." Milliyet, September 12, 1996.

40. Cotta, "Structuring the New Party Systems," 70. 
41. "On İsbatçı Mebus Dün DP'den Ayrıldı." Milliyet, October 16, 1955.

42. "Hürriyet Partisinin Kurulduğu Açıklandı." Milliyet, November 20, 1955.

43. Bilgiç, Hatıralar, 274 and Bozbeyli, Demokratik Să̆, 164-5.

44. Demokratik Parti, 72'ler Hareketi, 5-6.

45. Ibid., 46.

46. "Cindoruk'tan Start." Milliyet, March 28, 1996.

47. "DYP'de Ahlaki İsyan." Milliyet, July 3, 1996 and "Cindoruk: DYP Çiller'in Koruma Cemiyeti Oldu." Milliyet, July 24, 1996.

48. Yalman, Yakın Tarihte Gördüklerim, 327; Uraz, 1970 Siyasi Buhranı, 301-2; and "Cindoruk Ağır Konuştu." Milliyet, June 14, 1996.

49. Lucardie, "Prophets, Purifiers and Prolocutors," 177.

50. Sani and Todman, "Should We Stay or Should We Go?," 1647.

51. Tuncay, Parti içi Demokrasi, 74; Çapoğlu, "Açılış Konuşması," 2; Keçeciler, "Parti içi Demokrasi Bakımından," 33; and Turan, "Uzmanların Değerlendirmesi," 78.

52. Demirel, Adalet Partisi, 32.

53. Ibid., 44.

54. Çakmak, "Türk Siyasal Yaşamında," 162-3.

55. Cizre, "From Ruler to Pariah," 95.

56. Katz and Mair, "The Ascendancy of Party in Public Office," 121-6.

57. Gibson and Harmel. "Party Families and Democratic Performance," 216-7.

58. Adalet Partisi, Program ve Tüzük, Article 46; Demokrat Parti, Tüzük ve Programı, Article 17; and Doğru Yol Partisi, Tüzü̈̆̈̈̈, Article 39.

59. Unlike the DP, in which the GAC was responsible both for taking decisions and implementing them, the $\mathrm{AP}$ and DYP's by-laws stipulated the formation of separate decision-making organs. The Central Representative Council of the AP was composed of ex officio members and delegates selected by the provincial congresses. The Central Decision-Making Council of the DYP was composed of 70 members selected at the General Congress. However, in both cases, the power rested in the hands of the GACs.

60. Adalet Partisi, Program ve Tüzük, Article 88; Demokrat Parti, Tüzük ve Programı, Article 82; and Doğru Yol Partisi, Tüzü̈̆̈̈̈, Article 64.

61. Adalet Partisi, Program ve Tüzük, Article 78; Demokrat Parti, Tüzük ve Programi, Article 24; and Doğru Yol Partisi, Tüzü̈̆̈̈̈, Article 58.

62. Adalet Partisi, Program ve Tüzük, Article 120; Demokrat Parti, Tüzük ve Programl, Article 92; and Doğru Yol Partisi, Tüzü̈̆̈̈̈, Article 78.

63. Adalet Partisi, Program ve Tüzük, Article 119 and Doğru Yol Partisi, Tüzüğ̈̈, Article 78.

64. Adalet Partisi, Program ve Tüzük, Article 42; Demokrat Parti, Tüzük ve Programı, Article 57; and Doğru Yol Partisi, Tüzü̈̆̈̈, Article 36.

65. Michels, Political Parties, 135.

66. Adalet Partisi, Program ve Tüzük, Article 55; Demokrat Parti, Tüzük ve Programı, Article 17; and Doğru Yol Partisi, Tüzü̆ğ̈̈, Article 38.

67. "Hürriyet Partisinin Kurulduğu Açıklandı." Milliyet, November 20, 1955; Bozbeyli, Demokratik Să̆, 192-3; and "Arapsaçı." Milliyet, December 2, 1995.

68. Adalet Partisi, Süleyman Demirel'in Açıllş̧ Konuşması, 18.

69. "19 Mebusa Müdafaa için Mehil Verildi." Milliyet, October 14, 1955.

70. Ahmad, The Making of Modern Turkey, 112 and Demokratik Parti, 72'ler Hareketi, 42.

71. "Çiller'in Kader Seçimi." Milliyet, December 19, 1995.

\section{Notes on Contributor}

Özhan Demirkol is a PhD candidate in Political Science at Bilkent University, Ankara. He has a BS degree in Political Science and Public Administration from Bilkent University. He was awarded a master's degree from the Department of International Relations at Bilkent University. His research areas include Turkish political history and party politics. 


\section{Bibliography}

Adalet Partisi. Program ve Tüzük. Ankara: Doğuş Matbaacılık, 1966.

Adalet Partisi. Adalet Partisi Genel Başkanı Süleyman Demirel'in AP Altıncı Büyük Kongresini Açış Konuşması. Ankara: Doğuş Matbaacılık, 1972.

Ahmad, Feroz. The Making of Modern Turkey. London: Routledge, 2003.

Başlevent, Cem, Hasan Kirmanoğlu, and Burhan Şenatalar. "Empirical Investigation of Party Preferences and Economic Voting in Turkey." European Journal of Political Research 44 (2005): 547-562.

Bilgiç, Saadettin. Hatıralar. 2nd ed. Ankara: Boğaziçi Yayınları, 2002.

Bozbeyli, Ferruh. Demokratik Să̆. İstanbul: Dergah Yayınları, 1976.

Bochsler, Daniel. "The 'Normalization' of Party Systems and Voting Behavior in Eastern Europe." Romanian Journal of Political Science 5, no. 1 (2005): 53-74.

Çakmak, Diren. "Türk Siyasal Yaşamında Bir Muhalefet Partisi Örneği: Hürriyet Partisi (1955-1958)." Akademik Bakış 2, no. 3 (2008): 153-186.

Çarkoğlu, Ali. "The Turkish System in Transition: Party Performance and Agenda Setting." In Parties and Democracy?: Party Structure and Party Performance in Old and New Democracies, edited by Richard I. Hofferbert, 122-149. Oxford: Blackwell, 1999.

Çapoğlu, Gökhan. “Açılış Konuşması." Paper presented at the Intraparty Democracy Symposium, Ankara, April 10-11, 1-10. Ankara: ANSAV (Anadolu Stratejik Araştırmalar Vakfi), 1997.

Charney, Craig. "Class Conflict and the National Party Split." Journal of Southern African Studies 10, no. 2 (1984): 269-282.

Cizre, Ümit. "From Ruler to Pariah: The Life and Times of the True Path Party." Turkish Studies 3, no. 1 (2002): 82-101.

Cole, Alistair M. "Factionalism, the French Socialist Party and the Fifth Republic: An Explanation of IntraParty Divisions." European Journal of Political Research 17 (1989): 77-94.

Colomer, Josep M., ed. The Handbook of Electoral System Choice. New York: Palgrave Macmillan, 2004.

Cotta, Maurizio. "Structuring the New Party Systems After the Dictatorship: Coalitions, Alliances, Fusions and Splits During the Transition and Post-Transition Phase." In Stabilizing Fragile Democracies: Comparing Party Systems in Southern and Eastern Europe, edited by Geoffrey Pridham and Paul G. Lewis, 69-99. London: Routledge, 1996.

Demirel, Tanel. Adalet Partisi: İdeoloji ve Politika. İstanbul: İletişim Yayınları, 2004.

Desposato, Scott W. "Parties for Rent? Ambition, Ideology, and Party Switching in Brazil's Chamber of Deputies." American Journal of Political Science 50, no. 1 (2006): 62-80.

Desposato, Scott W. and Ethan Scheiner. "Governmental Centralization and Party Affiliation: Legislator Strategies in Brazil and Japan.” American Political Science Review 102, no. 4 (2008): 509-524.

Demokrat Parti. Tüzük ve Programı. Ankara: Güneş Matbaacılık, 1952.

Demokratik Parti. 72'ler Hareketi ve Demokratik Parti. Ankara: Demokratik Parti Genel Merkezi, 1971.

Doğru Yol Partisi. Doğru Yol Partisi Tüzüğ̈̈. Ankara: Şafak Matbaacılık, 1990.

Enyedi, Zsolt. "Party Politics in Post-Communist Transition." In Handbook of Party Politics, edited by Richard S. Katz and William Crotty, 228-238. London: Sage, 2006.

Gibson, Rachel, and Robert Harmel. "Party Families and Democratic Performance: Extraparliamentary vs. Parliamentary Group Power." In Parties and Democracy: Party Structure and Party Performance in Old and New Democracies, edited by Richard I. Hofferbert, 211-228. Oxford: Blackwell, 1998.

Gürkan, Ahmet. 50. Yll 1919-1973 Cumhuriyet, Meclis, Hükümetler, Başkanlar. 27 Mayls-12 Mart. Ankara: Güneş Matbaacılık, 1973.

Harmel, Robert, and John D. Robertson. "Formation and Success of New Parties: A Cross-National Analysis." International Political Science Review 6, no. 4 (1985): 501-523.

Hazama, Yasushi. Electoral Volatility in Turkey: Cleavages vs. the Economy. Chiba: Institute of Developing Economies, 2007.

Heller, William B., and Carol Mershon. "Switching in Parliamentary Parties?: Exits and Entries in Parliamentary Groups in the Italian Chamber of Deputies, 1996-2001." Paper presented at the annual meeting of the American Political Science Association, Philadelphia, PA, August 28-31, 2003. 
Hug, Simon. "Studying the Electoral Success of New Political Parties: A Methodological Note." Party Politics 6, no. 2 (2000): 187-197.

Hug, Simon. Altering Party Systems: Strategic Behavior and the Emergence of New Political Parties in Western Democracies. Ann Arbor, MI: The University of Michigan Press, 2001.

Inglehart, Ronald, and Scott C. Flanagan. "Value Change in Industrial Societies." The American Political Science Review 81, no. 4 (1987): 1289-1319.

Ignazi, Piero. "The Silent Counter-Revolution. Hypotheses on the Emergence of Extreme Right-Wing Parties." European Journal of Political Research 22 (1992): 3-34.

Inglehart, Ronald. "The Silent Revolution in Europe?: Intergenerational Change in Post-Industrial Societies." The American Political Science Review 65, no. 4 (1971): 991-1017.

Kalaycıŏlu, Ersin, and Ali Çarkoğlu. Turkish Democracy Today: Elections, Protest and Stability in an Islamic Society. London: I.B. Tauris, 2007.

Katz, Richard S., and Peter Mair. "The Ascendancy of Party in Public Office: Party Organizational Change in Twentieth-Century Democracies." In Political Parties: Old Concepts and New Challenges, edited by Richard Gunther, Jose Ramon Montero, and Juan J. Linz, 113-135. New York: Oxford University Press, 2001.

Katrak, Savak. "India's Communist Party Split.” The China Quarterly 7 (1961): 138-147.

Kaynar, Mete Kaan, Doğancan Özsel, Ozan Çavdar, Erdem Altaylı, Barış Mutluay, Safiye Ateş, and Uğur Sadioğlu. Cumhuriyet Dönemi Siyasi Partileri (1923-2006). Ankara: İmge Kitabevi, 2007.

Keçeciler, Mehmet. "Parti içi Demokrasi Bakımından Siyasi Partiler." Paper presented at the Political Parties and Democracy Symposium, Ankara, June 17, 27-37. İstanbul: TESAV (Toplumsal Ekonomik Siyasal Araştırmalar Vakfi), 1995.

Krouwel, André, and Onno Bosch. "Explaining the Emergence of New Parties: Cynical Citizens and the Rise of Populism." Paper prepared for Politicologenetmaal, Antwerpen, 27-28, 2004.

Lago, Ignacio, and Ferran Martinez. "Why New Parties?" Party Politics 17, no. 1 (2011): 3-20.

Lucardie, Paul. "Prophets, Purifiers and Prolocutors: Towards a Theory on the Emergence of New Parties." Party Politics 6, no. 2 (2000): 175-185.

Mainwaring, Scott. "Politicians, Parties, and Electoral Systems: Brazil in Comparative Perspective." Comparative Politics 24, no. 1 (1991): 21-43.

Michels, Robert. Political Parties: A Sociological Study of the Oligarchical Tendencies of Modern Democracy. Kitchener: Batoche Books, 2001.

Nutku, Emrullah. Demokrat Parti Neden Çöktï ve Politika'da Yitirdiğim Yıllar 1946-1958, Siyasal Anılarım. İstanbul: Fakülteler Matbaası, 1979.

Nuvunga, Adriano, and José Adalima. Mozambique Democratic Movement (MDM): An Analysis of a New Opposition Party in Mozambique. Maputo: Friedrich-Ebert-Stiftung Mozambique, 2011.

Olson, David M. "Party Formation and Party System Consolidation in the New Democracies of Central Europe." Political Studies XLVI (1998): 432-464.

Özbudun, Ergun, and Frank Tachau. "Social Change and Electoral Behavior in Turkey: Toward a 'Critical Realignment'?" International Journal of Middle East Studies 6, no. 4 (1975): 460-480.

Sakallığlu, Ümit Cizre. AP-Ordu İlişkileri: Bir İkilemin Anatomisi. İstanbul: İletişim Yayınları, 1993.

Sani, Fabio, and John Todman. "Should We Stay or Should We Go? A Social Psychological Model of Schisms in Groups." Personality and Social Psychology Bulletin 28, no. 12 (2002): 1647-1655.

Sayarı, Sabri. "The Turkish Party System in Transition." Government and Opposition 13, no. 1 (1978): $39-57$.

Selb, Peter, and Sandrine Pituctin. "Methodological Issues in the Study of New Parties' Entry and Electoral Success." Party Politics 16, no. 2 (2010): 147-170.

Simav, Akın. Turan Güneş'in Siyasi Kavgaları. İzmir: İstiklal Matbaası, 1975.

Tavits, Margit. "Party Systems in the Making: The Emergence and Success of New Parties in New Democracies." British Journal of Political Science 38 (2007): 113-133.

Tezcür, Güneş Murat. "Trends and Characteristics of the Turkish Party System in Light of the 2011 Elections." Turkish Studies 13, no. 2 (2012): 117-134.

Tuncay, Suavi. Parti içi Demokrasi ve Türkiye. Ankara: Gündoğan Yayınları, 1996. 


\section{$114 \ddot{O}$. Demirkol}

Turan, İlter. "Uzmanların Değerlendirmesi." Paper presented at the Intraparty Democracy Symposium, Ankara, April 10-11, 76-81. Ankara: ANSAV (Anadolu Stratejik Araştırmalar Vakfı), 1997.

Türkiye Büyük Millet Meclisi. TBMM Albümü (1920-2010). Ankara: TBMM Basın ve Halkla İlişkiler Müdürlüğ̈̈, 2010.

Türkiye İstatistik Kurumu. Milletvekili Genel Seçimleri (1923-2007). Ankara: Türkiye İstatistik Kurumu Matbaas1, 2008.

Uraz, Abdullah. 1970 Siyasi Buhranı ve İç Yüzü. İstanbul: Son Havadis Yayınları, 1970.

Yalman, Ahmet Emin. Yakın Tarihte Gördüklerim ve Geçirdiklerim Cilt IV (1945-1970). İstanbul: Yenilik, 1970.

Zürcher, Erik J. Turkey: A Modern History. London: I.B. Tauris, 2004.

Willey, Joseph. "Institutional Arrangements and the Success of New Parties in Old Democracies." In Parties and Democracy: Party Structure and Party Performance in Old and New Democracies, edited by Richard I. Hofferbert, 229-246. Oxford: Blackwell, 1999.

\section{Appendix}

The effective number of parliamentary parties is calculated by first taking the seat share of each party as a decimal, squaring this value, and summing these values for all parties. Independents are ignored. The figure obtained is then inverted.

Volatility for the pre-1980 period is calculated according to the Pedersen formula, bearing in mind the points raised by Güneş Murat Tezcür (2012). Actual formulas are

$$
\begin{aligned}
& 1954-1950=\sum(\mid \mathrm{DP} 54+\text { TKP54 }- \text { DP50||CHP54 }- \text { CHP50||CMP54 } \\
& \text { - MP50||IP54 - 0||Independents54 - Independents50|)/2, } \\
& 1957-1954=\sum(\mid \text { DP57 + HP57 }- \text { DP54||CHP57 }- \text { CHP54||CMP57 } \\
& \text { - CMP54||VP1957 - 0||Independents57 - Independents54|)/2, } \\
& 1961-1957=\sum(\mid \text { CHP61 }- \text { CHP57 }+ \text { HP57||AP61 }+ \text { YTP61 } \\
& \text { - DP57||CKMP61 - CMP57||Independents61 } \\
& \text { - Independents57|)/2, } \\
& 1965-1961=\sum(\mid \text { CHP65 }- \text { CHP61||AP65 }- \text { AP61||YTP65 } \\
& \text { - YTP61||CKMP65 + MP65 - CKMP61||TIP65 } \\
& -0|| \text { Independents65 - Independents61|)/2, } \\
& 1969-1965=\sum(\mid \text { CHP69 }+ \text { GP69 }- \text { CHP65 ||AP69 }- \text { AP65||MHP69 } \\
& \text { - CKMP65||YTP69 - YTP65||TIP69 - TIP65||MP69 } \\
& \text { - MP65||BP69 - 0||Independents69 - Independents65|)/2, } \\
& 1973-1969=\sum(\mid \mathrm{CHP} 73+\mathrm{CGP73}-\mathrm{CHP} 69-\text { GP69||AP73 + DkP73 } \\
& \text { - AP69||MHP73 - MHP69||MSP73 - 0||MP73 - MP69||TBP73 } \\
& \text { - BP69||Independents73 - Independents69|)/2, } \\
& 1977-1969=\sum(\mid \text { CHP77 }- \text { CHP73||AP77 }- \text { AP73||DkP77 - Dkp73||MSP77 } \\
& \text { - MSP73||MHP77 - MHP73||TBP77 - TBP73||CGP77 } \\
& \text { - CGP73||TIP77 - 0||Independents77 - Independents73|)/2. }
\end{aligned}
$$

